\title{
ANALYSIS OF RELEVANT SAFETY PROBLEMS OF ENVIRONMENTAL IMPACT IN ENERGETICS
}

\section{Poliakova Iryna ${ }^{1}$ \\ Borovik Volodymyr ${ }^{2}$}

DOI: https://doi.org/10.30525/978-9934-571-78-7_58

Abstract. Nuclear power industry is a field of power engineering that
uses nuclear power for electrification and heating, as well as it is a field of
science and technology that develops methods and means for transformation
of nuclear energy into electrical and heat energy. The nuclear energy
among other types of the energy comprises such advantages as a high
heat generating capability of the nuclear fuel ( 2 mln times greater than oil,
and 3 mln times greater than coal), better economic indicators, and less
pollution of the environment. In addition, the reactor operation does not cause combustion reaction, where oxygen is used to support the reaction. Whereas, for other types of energy the oxygen is combusted five times more than it is consumed by all living beings. Besides, the stock of raw materials used for nuclear fuel production is approximately twenty times greater than the stock of organic fuel of all kinds [1-3]. Most nuclear energy adherents believe that efforts should be focused on elimination of the public distrust as for the safety of nuclear technologies. Nuclear energy is a reliable source of power supply and it plays a leading role in addressing energy needs of Ukraine. Especially, when the country is under the conditions of economic crisis, when there is no sufficient natural fuel, no funds for modernization of the equipment of thermal and hydroelectric power plants, and for development of non-traditional sources of energy generation. Generation of electricity allows for keeping the wholesale electricity tariff at the acceptable level and reduces the greenhouse gas releases into the atmosphere. The nuclear power plants produce about $50 \%$ of the electricity consumed in the country, which is equivalent to combustion of about

\footnotetext{
${ }^{1}$ Candidate of Technical Sciences,

Head of the Department of Nuclear Technology and Radiation Safety, LLC "TechnoChemAtom", Ukraine

${ }^{2}$ Head of the Department of Engineering and Environmental Research, Kyiv Research Institute of Forensic Experts Ministry of Justice of Ukraine, Ukraine
} 
$40 \mathrm{mln}$ tons of coal per year. Lifetime extension of the operating nuclear power units is defined in "Energy Strategy of Ukraine for the period up to 2030 " as one of the necessary conditions for implementation of goals and tasks of this strategy. The activities related to lifetime extension of the operating power units are regulated by the international agreements ratified by Ukraine, laws of Ukraine and substatutory regulatory acts. Lifetime extension of the Ukrainian NPPs over the designed period will allow the state to ensure both the support of electricity production at the achieved level prior to introduction of new capacities, and save the necessary funds for power units decommissioning without significant load increase onto the consumer. The priority of ensuring protection to a human and environment from the negative impact of ionizing radiation, ensuring safety during application of nuclear energy is one of the main principles of the national policy in the area of usage of nuclear energy and radiation protection of Ukraine. Specifically, in line with the Law of Ukraine on Usage of Nuclear Energy and Radiation Protection [4], Article 8, "Adherence to norms, rules and standards on nuclear and radiation safety is obligatory when performing any type of the activity in the area of nuclear energy".

"The mankind has two global problems where to get energy and how to safely get rid of the waste"

E.V. Sobotovich

\section{Introduction}

The main types of possible impact onto the environment of NPP site during plant operation, based on the working process, are radiation, chemical and non-radiological physical impact. Under the normal operation conditions the significant ones are thermal (non-radiological physical impact), chemical and radiation impact (enumerated as per the order of significance). For low-probability but possible cases of maximum designbasis or beyond-design basis accident, the dominant one is the radiation impact.

Reliability and profitability of the electricity produced by the nuclear power plants are recognized worldwide. Under the conditions of unstable markets and increased prices for gas, oil and coal, the importance of nuclear energy in meeting the needs of production areas and public are increasing in terms of relatively cheap electricity. 
The design of NPP units in Ukraine implies the defense in depth concept, which is based on the levels of proteciton and incorporates series of subsequent barriers on the way of radioactive release into the environment. The designed safety systems that ensure emergency protection and emergency core cooling of the reactor facility are the following:

- safety protecting systems;

- safety isolating systems;

- safety supporting systems;

- safety controlling systems.

The power units of Rivne NPP were designed, constructed and erected in accordance with the regulatory documents that were in force at that time.

In 1971, the designing of Western Ukrainian NPP was initiated, which afterwards was renamed into Rivne NPP. The power plant is intended to cover electrical loads in the western part of the country.

SS "Rivne NPP" is the first nuclear power plant in Ukraine with waterwater power reactor of VVER-440 type. The unit construction started in 1973. The two first power units with VVER-440/213 were put into operation in 1980-1981, and the third power unit with VVER-1000/320 reactor was commissioned in 1986.

The operation time for Rivne NPP power units is presented in Table 1.

Table 1

Information on the power units of Rivne NPP

\begin{tabular}{|c|c|c|c|c|c|c|}
\hline $\begin{array}{c}\text { Power } \\
\text { unit }\end{array}$ & $\begin{array}{c}\text { Type of } \\
\text { reactor } \\
\text { facility }\end{array}$ & $\begin{array}{c}\text { Series } \\
\text { of } \\
\text { reactor } \\
\text { facility }\end{array}$ & $\begin{array}{c}\text { Date } \\
\text { of unit } \\
\text { connection } \\
\text { to the grid }\end{array}$ & $\begin{array}{c}\text { Date of } \\
\text { putting the } \\
\text { unit into } \\
\text { commercial } \\
\text { operation }\end{array}$ & $\begin{array}{c}\text { Date of } \\
\text { design } \\
\text { lifetime }\end{array}$ & $\begin{array}{c}\text { Date of } \\
\text { lifetime } \\
\text { extension }\end{array}$ \\
\hline RNPP-1 & VVER-440 & B-213 & 22.12 .1980 & 22.09 .1981 & 22.12 .2010 & 22.12 .2030 \\
\hline RNPP-2 & VVER-440 & B-213 & 22.12 .1981 & 29.07 .1982 & 22.12 .2011 & 22.12 .2031 \\
\hline RNPP-3 & VVER-1000 & B-320 & 21.12 .1986 & 11.12 .1987 & 11.12 .2017 & 22.12 .2037 \\
\hline RNPP-4 & VVER-1000 & B-320 & 10.10 .2004 & 07.06 .2005 & 07.06 .2035 & - \\
\hline
\end{tabular}

Annually the SS "Rivne NPP" produces about 19 milliards kWt×year of electricity, which makes $21.6 \%$ from the electricity production by the NPPs or $13.0 \%$ from the total electricity production.

As of 2018 Rivne NPP operates four power units:

- unit I (VVER-440) with capacity of 420 thousands kWt from 1980; 
- unit II (VVER-440) with capacity of 415 thousands kWt from 1981;

- unit III (VVER-1000) with capacity of 1 thousands kWt from 1986;

- unit IV (VVER-1000) with capacity of 1 thousands kWt from 2004.

The power units of Rivne NPP meet the up-to-date requirements of nuclear and radiation safety, which is confirmed by the reviews of International Atomic Energy Agency $(1988,1996,2003,2005,2008)$ and World Association of Nuclear Operators (1988, 1989, 1993, 1995, 1997, 2001, 2003, 2005, 2012, 2014, 2015, 2016, 2018 years).

The cooling system of Rivne NPP power units does not include the cooling ponds. The entire system for power units cooling is designed such that to use six cooling towers and spray ponds.

The controlled area (CA) is established around the nuclear radiation facility. The criterion for establishing the controlled area are the limits of the annual absorption of radioactive substances through the breathing organs and digestion organs, and doze margins of external exposure of the personnel and public, as well as allowed concentration of radioactive substances in the atmospheric air and water.

The CA size is defined with consideration of the assessed radiation conditions in the area of the plant location during its long-term operation.

The region of Rivne NPP location and the borders of its observation zone $(\mathrm{OZ})$ and controlled area (CA) are presented on Figure 1.

The OZ size of Rivne NPP is bounded with the radius of $2.5 \mathrm{~km}$ around the radiation hazardous facilities. The observation zone constitutes $30 \mathrm{~km}$.

The sizes of SCA and OZ are officially introduced in accordance with the document of RNPP, specifically "Solution on the size and boundaries of the sanitary and controlled area and observation zone of Rivne NPP", No 132-1-P-11-ЦРБ [5].

The plant safety systems that ensure public protection during accidents, including the design basis accidents with the most severe consequences, which are designed such that the values of equivalent individual doze rates calculated for

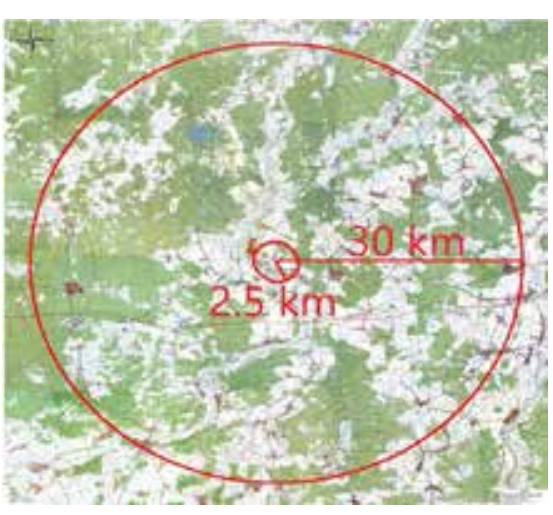

Figure 1. The territory of SS "Rivne NPP" 
the worst weather conditions on on the border of SCA and beyond that does not exceed $3 \mathrm{mZv} /$ year for the thyroid for children due to inhalation intake and $1 \mathrm{mZv} / y e a r$ for the entire body due to external exposure [6].

The observation zone includes the territory with possible impact of radiological effluents and releases of the nuclear radiation facility (NPP) and places with implemented monitoring.

For the purpose of justification of the above mentioned, the comparative analysis of the impact of nuclear and thermal power plants can be provided.

2. Actual problems of impact of TPPs to environmental

The thermal power plants (TPP) make more impact on the environment than NPPs. Because of chimneys, the TPPs release the effluent gases into the atmosphere, which contain not only nitrogen and remaining amount of oxygen but also carbon dioxide, water vapor, sulfur dioxide, nitrogen oxides and fly ash, which were not captured by the electrical filters.

The bigger problem in terms of environmental impact is the solid radioactive waste of coal dust TPPs such as ash and slag. Significant areas of land are designated for storage of this waste. During the long-term storage of ash and slag, different kinds of products are leached, which then enter the ground waters.

The most dangerous one for the atmosphere is the release of carbon compounds that leads to the greenhouse effect, which further on can cause global warming of the Earth. This phenomenon will bring to the following events:

- increase of number of storms and hurricanes;

- flooding of the low-lying ground (water level increase for 1 meter will flood the territory, where 1 milliard people live);

- relocation of fertile areas and reduction of harvests due to droughts and ground erosion in some regions and excessive humidity in other regions;

- extinction of some species of animals and plants;

- losses of fresh water resources in some regions, formation of deserts.

The negative impact on the environment is imposed by the substances that result from burning of organic matters: sulfur dioxide and nitrogen oxides. During their interaction with the water drops of the clouds and rain, they form acids and then acid salts, which are very often toxic. This compounds fall to the ground in the form of acid rains, which influence the flora and acidify the waters and soils.

Extremely harmful emissions of natural radionuclides during combustion, namely radium, thorium, potassium-40, etc., are thousands of times higher than radioactive emissions from nuclear power plants. 


\section{Actual problems of impact of NPPs to environmental}

Radiation impact. During plant operation, it is inevitable to have gaseous, solid and liquid materials, which contain radionuclides in their composition (radioactive isotopes of the chemical elements). The radiation impact of the power units is conditioned by the releases of these materials into the atmosphere.

Under the normal operation conditions, any release of radioactive nuclides (fission products) outside the fuel elements cladding will lead to radioactive contamination of the primary coolant.

Substantial amount of radioactive products enter the primary coolant as a result of neutron activation in the structural materials and processes of erosion and corrosion of these materials.

In addition, air activation processes, in the close vicinity to the reactor vessel, will cause generation of insignificant amount of gaseous radioactive particles including evaporation of tritium water and inert gases.

Radioactive fission and activation products are drawn from the coolant because of ion exchange processes, which leads to generation of contaminated ion exchange resins in the special water purification (SWP) installations. Periodic change of these resins result in formation of liquid and solid radioactive waste.

Treatment of the radioactive medium at the SWP installations located in the special building will lead to generation of radioactive waste: solid, liquid and gaseous.

The circulation of coolant, flowing in the steam generator from the primary into secondary circuit, lead to formation of the contaminated water in this circuit.

Gases accumulated in the primary side generate the flow of gaseous release. Releases into atmosphere can also occur as a result of ventilation of the volatile matters of the primary coolant, which occur in the event of small leaks, controlled and uncontrolled leakages. As a rule, such types of releases have tritium water vapor, inert gases, aerosols and other gaseous particles.

During the annual reactor shutdown, the pressure is reduced using the cooling system, the reactor head is removed and one third of the fuel assemblies is withdrawn and moved to the spent fuel pit (SFP) for further cooling and storage. The other two third of the fuel assemblies are rearranged to support the optimal leak-tightness of the neutron flow density, and then the reactor core is loaded with the fresh fuel. The refueling operations can 
lead to increase of the liquid radioactive waste (LRW) releases and releases to the air from the spent fuel pit, reactor inspection shaft and guide tubes shaft. These releases by the nature are similar to the releases generated from the coolant in the primary side.

Besides, the repair and maintenance activities conducted during the reactor shutdown can be also a potential source for radioactive waste, which occurs as a result of opening and repairing of the equipment. Individual components of the primary circuit, which are contaminated due to neutron irradiation, as well as elements of the equipment of reactor hall and special building imposed to radioactive contamination, can be replaces, which leads to additional amount of solid radwaste.

LRW and SRW treatment and storage is accomplished in accordance with the requirements of "Sanitary rules of plant design and operation" [7]. Release of this type of waste into the environment during plant normal operation, design-basis accidents and probable beyond design-basis accidents is practically excluded.

Designing of the nuclear reactors involves one of the main safety principles, which is defense in depth concept. According to this concept, several layers of security are placed to prevent or limit adverse consequences from the equipment failures and plant personnel errors.

The main important requirement of the defense in depth principle is establishment of the safety barriers. Due to a potential of fission fragments spreading from the nuclear fuel and their release into the environment, the modern reactors incorporate three barriers, which can be considered as safety barriers based on their functions and significance. The first safety barrier is the nuclear fuel itself and fuel elements cladding. If the radioactive products get into the coolant, their spreading is blocked by the reactor coolant system (RCS), pipelines and RCS vessel structures (the second safety barrier). Also, radioactive fission products are restrained either by the system of hermetically sealed compartments or containment (the third barrier).

During normal plant operation, these barriers ensure safety of the personnel, public and environment.

Three points are established to conduct monitoring of impact of liquid discharges from Rivne NPP into the Styr River:

- Mayunychi Village - $10 \mathrm{~km}$ up the river stream;

- below the drain point of industrial and storm sewage system;

- Sopachiv village - $10 \mathrm{~km}$ down the river stream. 


\section{Chapter «Engineering sciences»}

The sampling is performed once per a decade and then the specific activity of natural and man-made radionuclides is determined using semiconductive $\gamma$-spectrometers. The tritium activity is determined by the liquid scintillation radiometer Tri-Carb $3170 \mathrm{TR} / \mathrm{SL}$.

The concentration of radionuclides is thousand times lower in the Styr River than the allowed radionuclides concentration in portable water [6].

The bottom sediments, weed and fish of the Styr River are sampled in August every year. The samples go through preliminary verification and $\gamma$-spectrometric analysis. The objects of the Styr River have no man-made radionuclides except for $137 \mathrm{Cs}$ of Chernobyl origin. The specific activity of 137Cs in the fresh fish is 100 times less than the established allowed level [8].

To control non-spreading of the radioactive materials into the ground waters, the radiation monitoring of underground waters is conducted on the territory of Rivne NPP site. To control the underground water supply sources, the content of radionuclides is measured in the artesian wellholes.

There are 35 check-wellholes, and water is sampled from the bottom layer at a depth of $10 \div 14$ meters from the surface. The frequency of water sampling from the check and artesian wellholes is once per quarter [9]. Each sample is measured in terms of $\Sigma \beta$-activity using $\alpha / \beta$ radiometer MPC9604 and specific activity of tritium is measured using liquid scintillational radiometer Tri-Carb $3170 \mathrm{TR} / \mathrm{SL}$. The samples of check-wellholes are averaged and are subject to $\gamma$-spectrometeric analysis. The activity of manmade isotopes in the groundwaters is thousand times less than the level of allowed concentration in the portable water.

The network of artesian well-holes consists of nine wells, organized on the territory of the water withdrawal point "Ostriv". The samples of water are taken from the special collector, and go through $\gamma$-spectrometry and measurement of tritium activity. The water of artesian wellholes has no isotopes of manmade nature.

Sampling and monitoring of the aerosol content in the surface atmospheric layer is performed in accordance with "Technical Specification of radiation monitoring of Rivne NPP" once per a decade at 16 monitoring points. The specific activity of manmade radionuclides in the atmospheric air for 37 years of observations did not exceed the regulatory values established by NRBU-97 [6]. For radionuclides $137 \mathrm{Cs}$ and $90 \mathrm{Sr}$ the specific activity is within the margins of "zero background". 
Gaseous and aerosol releases of radioactive substances, which entered into the atmosphere from the ventilation stacks, are spread in the atmosphere thus forming so-called "release cloud". The aerosol particles fall from the cloud, deposit on the ground and migrate in the elements that adjoin the ecological systems of NPP.

The results of multi-year observations show that $\Sigma \beta$-activity of the precipitations and the content of $137 \mathrm{Cs}$ and $90 \mathrm{Sr}$ for the observation period is within the margins of "zero background" and does not depend on the distance of the surveillance station from Rivne NPP.

Sampling of the soil is conducted in the continuous monitoring stations together with the sampling of vegetation layer. Samples are taken from April to May in 22 points/stations from the layer of $0 \div 5 \mathrm{~cm}$ and are measured by $\gamma$-spectrometers. The radionuclides content in the soil and vegetation was detected to be the radionuclides of natural and "Chornobyl" origin (137Cs).

The controlled area of Rivne NPP is subject to monitoring of the main local food products like milk, vegetables, and crops. The samples are taken during ripening period and go through measurements using $\gamma$-spectrometry in order to establish possible presence of radionuclides of manmade origin.

During the surveillance period, the agricultural products were identified to be free from the manmade radionuclides except for 137Cs of "Chornobyl" origin. The increased content of this radionuclide in the food products is conditioned by a large value of transition coefficients in the chain "soilsolution-plants" for the soil of this region.

Chemical impact. The chemical impact of Rivne NPP site on the environment comprises the contaminant effluents into the Styr River, contaminant releases into the atmospheric air (separate: from plant and from mobile sources) and possible impact on the atmospheric air, soil and underwaters due to placing of waste in the locations of waste treatment. The sources of chemical releases from the NPP into the environment are:

- evaporation of the additional source river water in the circulating water systems (increased concentration of chemical substances in water) and catching of contaminants by filtering materials and purification installations;

- combustion of diesel oil, fuel oil residue, gasoline and other kinds of fossil fuel;

- evaporation and loss of reagents during receipt and usage (acids, alkalis, oils, fuel);

- dust emissions during mechanic processing of metals and wood; 


\section{Chapter «Engineering sciences»}

- aerosol emissions during metal welding and cutting;

- painting of equipment and building structures, erosion;

- corrosion and scraping of equipment surfaces;

- waste formation from used, unserviceable, replaced equipment.

The design and production documentation take into account the chemical impact on the environment during normal, abnormal plant operation and emergencies/accidents.

Rivne NPP is an entity with a large number of necessary additional production facilities. The entity is under the state accounting in the field of atmospheric air protection. It has 290 automobiles, among them 142 diesel items, 148 gasoline items, and 7 items belong to railway transport. Two certified check and adjusting stations operate for the automobile diagnosis and measurement of toxicity and smokiness of exhaust gases.

The site of Rivne NPP comprises 164 stationary sources of releases into the atmosphere, 40 contaminating non-radioactive substances. The post probable release source is the auxiliary boiler station, designed for sulphur oil burning. From 1994, there was no need in using the auxiliary boiler station; its boilers are started one per year with the minimum capacity and only for the purposes of personnel training and verification of the equipment. The stationary sources of releases into the atmospheric air are located in seven production sites of Rivne NPP. The contaminant releases into the atmospheric air from the stationary sources of every site are made on the basis of special permissions, issued in particular by:

- rehabilitation and recreation center "White Lake" near the village Bilska Volya of Volodymyrets region, the permission duration period is not limited;

- car fleet of transport facility in the industrial area No 2 (northern) of the town of Varash, the duration period is 5 years;

- site of power units in the industrial area No 1 (southern) of the town Varash, the duration period is 5 years;

- vocational technical school and sport complex in the district of Peremogy of the town Varash, the duration period is not limited;

- divisions, automatic radiation monitoring center, the cold-storage warehouse on the streets Teplychna, Rynkova, Komunalna, Energetykiv of the town Varash, the duration period is not limited;

- divisions, asphalt factory on the construction base of the town of Varash, the duration period is 10 years; 
- treatment facilities of domestic sewerage division on the street Dachna of the town of Varash, the duration period is not limited.

The requirements and conditions of permissions are specified in the inspection time schedule, agreed with the Rivne Oblast State Administration. This schedule is developed and accomplished to verify compliance with the established allowable release limits of the contaminants, as well as conditions of permits for releases into the atmospheric air from the stationary sources.

Fourteen atmospheric release points are equipped with the gas treatment installations (GTIs). All gas treatment installations have passports. The gas treatment equipment is operated in accordance with "Rules for operation of gas treatment facilities". By the order of General Director of Rivne NPP, the people are assigned who are responsible for GTIs operation. According to the design documentation and operation conditions, the operating instructions were developed for each GTI The body of installations have applied registration numbers as per their passports. The accounting records are maintained with regard to operation time for each gas treatment installation.

Rivne Oblast State Administration submits the annual reports of Form 2-TP (air) in a timely manner to the Department of Ecology and Natural Resources. Reports are prepared using the quantitative method based on the data regarding the used raw products, fuel, materials and time of facilities operation. The stationary sources of Rivne NPP release from 33 to 37 tonnes of contaminant substances into the atmosphere for a year. Among them:

- nonmethane volatile organic compounds - 18-25 t;

- nitrogen compounds - 5-9 t;

- substances in the form of suspended solids (microparticles and fibers) 1.4-2.7 t;

- sulphur compounds - 1.2-2.7 t.

Releases of the polluting substances into the atmosphere from the plant is 2-3 thousand times less than from the coal thermal power plant with the similar installed capacity.

The water from the cooling system returns back continuously to the river through one discharge point of the industrial storm water sewerage system, which is located $30 \mathrm{~m}$ below the river stream from the river (additional) water intake facility. The industrial storm sewerage system receives the blowdown water from the circulation systems continuously and other debalancing waters from the power unit sites periodically after calculation of non-exceedance 


\section{Chapter «Engineering sciences»}

of normative effluents of contaminating substances. In accordance with the permission on special water use, the allowed effluents are in the volume of up to 18409.0 thousand $\mathrm{m} 3$ of water for a year $\left(0.7 \mathrm{~m}^{3} / \mathrm{sec}\right)$.

Monitoring of the chemical composition of sewerage water and river water discharged to the water intake station of Rivne NPP and after the discharge point is conduced by the certified laboratories of the NPP. The laboratory of heat and ground communications take samples and performs analysis of the discharge water not less than six times a day (oil products and $\mathrm{pH}$ ).

The ecological and chemical laboratory of environmental protection service (EPS) performs analysis of the surface and sewerage (discharge) waters three times a week using 25 indicators. The analysis of monitored indicators prove that the values of the maximum allowed effluents (in tons) were not exceeded, the sewerage water is within the purity limits, and contains the same natural impurities like the source river water, and operation of Rivne NPP does not input the significant changes into the quality of surface waters.

The controlled area of the first ring of the Artesian wells of the village Ostriv are subtracted and enclosed. The analysis is conducted by the ecological and chemical laboratory certified for making measurements of chemical composition of groundwaters (drill holes/wells) in the area of sludge collector and landfill for construction and industrial waste from Rivne NPP. The analysis of monitored characteristics prove that Rivne NPP operation does not input significant changes into the quality of ground waters.

Thermal impact. Nuclear power plants are the sources of heat release into the atmosphere. The thermal impact of Rivne NPP on the environment should be considered in the context of microclimate impact. The microclimate in the area of Rivne NPP is formed under the influence of additional heat and humidity, which come into the atmosphere with the releases from cooling towers and spray ponds.

About $70 \%$ of thermal power generated in the reactors is not used for electricity production in the steam turbines, and it goes through the cooling systems to the environment. This released low-potential heat is transferred to the service water. This water transports the heat to the cooling towers and spray ponds, where it is transferred to the ultimate heat absorber, atmospheric air, due to convectional heat exchange and evaporated water cooling. 
Part of the heat, removed by the service water of the cooling system, is transferred to the River Styr through the permanently open blowdown line of the circulation systems. A small amount of heat produced from the heated walls of equipment, pipelines and cables in the processing areas and then ventilation systems and air conditioning is released to the atmosphere.

The impact of cooling towers and spray ponds onto the microclimate is analyzed for the Rivne NPP site in general, since the cooling system for all power units is geographically grouped in one place and induce a combined impact on the microclimates of near-surface layer of air by cappilary transport of humidity. It can be mostly intense during strong winds and only in close vicinity to the ponds (100-500 m). During a cold season of the year, the sprays in the ponds are turned off and the impact of the ponds during this period of time reduces to zero.

Heat and humidity releases from the spray ponds do not exceed $3 \%$ of the similar releases of the cooling towers, which accordingly make the same amount of heat in formation of the entire microclimate of Rivne NPP site.

The main contribution in measuring the plant region microclimate belongs to the cooling towers. Increase of the air temperature and humidity due to steam and drops release from the towers occurs mostly in the nearsurface layer of the atmosphere, at the height of 200-500 m.

Increase of the air temperature for about $0.5-1.00 \mathrm{C}$ in winter as per January background indicators, measured at the distance of $1 \mathrm{~km}$ from the cooling towers, and increase of the yearly amount of precipitations for $2-3 \%$ due to releases from steam-dropping flares of towers are subtle: in winter there can be glaze and rime.

Each power unit operates three cooling systems:

- circulation systems of service water supply;

- Group A service water cooling system (three independent trains with cooling of the spray ponds);

- Group B service water cooling system with cooling of two-section spray pond.

Table 2 presents the values of heat releases of Rivne NPP into atmosphere.

The existing regulatory documents do not have requirements to the allowed limits of heat releases. Monitoring of heat releases is performed by measuring the consumed water, which is collected from the River Styr for service needs and consumed water that returns to the river. 
Table 2

\section{Amount of heat removed by the cooling water from the plant components and released into atmosphere}

\begin{tabular}{|l|c|}
\hline \multicolumn{1}{|c|}{ Plant equipment } & Heat release, Gcal/year \\
\hline Circulation systems of service water supply & 5220 \\
\hline Group A service water supply system & 60 \\
\hline Group B service water supply system & 100 \\
\hline
\end{tabular}

Taking into account that impact of the plant cooling systems is quite insignificant on the climate parameters, and that impact of the cooling towers and spray ponds is practically implicit on the microclimate and environment outside the sanitary protection zone within the radius of $2.5 \mathrm{~km}$, no special activities are foreseen with regard to limitation of these influences during NPP operation.

\section{Production waste of NPP}

During the plant operation, it is inevitable to have the production waste: solid, liquid and gaseous.

Radioactive waste are the material objects and substances with the activity of radionuclides or radiation contamination exceeding the limits, established by the existing norms, with the condition that these objects and substances are not used. Radioactive waste is a special type of radioactive materials (in any physical form), in relation to which:

- it is determined that neither now or later they will be used, or

- the final decision is not yet taken with regard to how these materials can be used in the framework of modern or further developed technological processes [10]. Classification of radioactive waste is defined by the State Sanitary Rules DSP 6.177-2005-09-02 "Main sanitary rules for radiation safety of Ukraine (OSPU-2005)" [10].

Production of the electricity at the nuclear power plants comes along with generation of radioactive waste in the course of the main technological process, as well as during routine and maintenance operations. The stable development of the nuclear energy field in the country requires safe management of the radioactive waste at all phases of waste formation and existence. The radwaste management system is an important component in the entire safety systems while using nuclear energy. 


\section{Poliakova Iryna, Borovik Volodymyr}

The main principles of the radwaste management at the NPP is minimization of waste formation and interaction between all phases - from formation to disposal [11].

The strategy on radwaste management in Ukraine, approved by the Cabinet of Ministers of Ukraine and National Target Environmental Program for Radioactive Waste Management approved by the Law of Ukraine, specifies withdrawal and processing of radioactive waste accumulated during plant operation. It should be done through establishment of the infrastructure for radioactive waste specification, conditioning and packaging using the method applicable for its further transportation for storage and/or disposal.

The State Special Enterprise "Central Radioactive Waste Management Enterprise" (CRWME), the storage facilities operator, within the State Agency of Ukraine on Exclusion Zone Management (SAUMEZ) is responsible for acceptance and storage (if required, long-term storage) of the conditioned radwaste. Currently, NPP radwaste shipping for the longterm storage or disposal at the facilities is not accomplished, but activities were initiated on radwaste preparation for shipping to the special enterprise.

Planning of the activities on radioactive waste management at RNPP is accomplished in accordance with "Integrated Program for Radioactive Waste Management in NNEGC Energoatom" ПМ-Д.0.18.174-16 [12]. The program specifies main areas and a list of activities related to radioactive waste management in NNEGC Energoatom. These activities are: minimization of radwaste generation, improvement of the current radwaste management systems at NPPs sites, construction of complex lines on radwaste processing for its preparation to transference to the ownership of the state, provision the plant with the equipment for radwaste storage, harmonization and improvement of the regulatory framework in the area of radwaste management.

During planning the activities in the field of radioactive waste management, NNEGC Energoatom applies the following main principles:

$\checkmark$ ensure corresponding safety level in the field of radioactive waste management;

$\checkmark$ minimization of generated radwaste volumes during plant operation;

$\checkmark$ selection of optimal radwaste treatment technologies considering such factors as:

$\checkmark$ individual and collective radiation doses of the personnel;

$\checkmark$ cost of radwaste processing;

$\checkmark$ amount of generated radwaste; 
$\checkmark$ duration and cost of short-term radwaste storage;

$\checkmark$ requirements to the end product accepted for disposal;

$\checkmark$ capability of using selected methods of radwaste processing both during plant operation and its decommissioning;

$\checkmark$ ensure capability of processing, immobilization, and temporary storage of radwaste generated during extended lifetime of the plant;

$\checkmark$ application of the advanced technologies during radwaste processing and immobilization to provide for radwaste safe transportation and disposal;

$\checkmark$ ensure quality of all processes and works related to the radioactive waste management at the plant.

The main activity on improvement of the radioactive waste management system at Rivne NPP is construction of a complex for the radioactive waste processing (CRWP). The Program ПМ- Д.0.18.174-16 indicates commissioning of CRWP in 2018. A separate permission was obtained from the State Nuclear Regulatory Inspectorate of Ukraine (SNRIU) for operation of the new facility of the infrastructure - radioactive waste processing complex.

SNRIU ensured regulatory follow-up of the activity, review and agreement of the complex testing programs and corresponding technical solutions regarding putting of CRWP into trial operaiton at Rivne NPP within other process facilities:

- extraction of SRW from the SRW storage compartments;

- SRW sorting and fragmentation;

- SRW supepressing;

- SRW cementation;

- SRW activity measurement;

- metal decontamination;

- spent oil treatment.

Implementation of the radwaste complex will allow for:

- reduce the amount of accumulated SRW and waste generated during operation;

- condition the solid radioactive waste (SRW) to ensure its safe longterm storage and disposal;

- obtain additional free volumes in the existing storage facilities for the short-term storage of the containers with SRW under the ownership of the state.

Radwaste management at Rivne NPP is accomplished like at any other operating NPP in compliance with the principle flow chart presented below at Figure 2. 


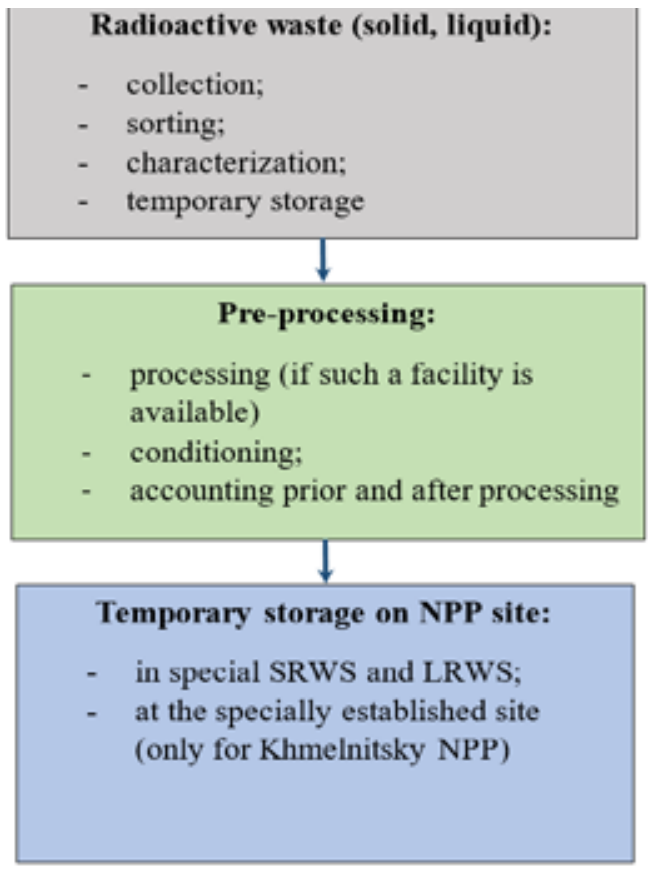

Figure 2. Principal flow chart for radioactive waste management at NPP
The condition of radwaste management at Ukrainian NPPs is characterized with absence of completed technological cycle from the processing to obtaining of the end-product, acceptable for further long-term storage or disposal.

At present, due to unreadiness of the Operator of CRWME storages, which is under subordination to the State Agency of Ukraine for the of Exclusion Zone Management, with regard to receiving the NPP radwaste for its longterm storage and disposal, radwaste transfer to this specialized enterprise is not accomplished.

\subsection{Solid radioactive waste management during plant operation}

The solid radioactive waste (SRW) generates in the process of normal plant operation, during maintenance and repair activities and during accidents [12].

The main source of SRW generation is maintenance and repair activities at the power units, which include:

- operation of the plant components, buildings and facilities;

- reconstruction and modernization of equipment;

- decommissioning of components, including replacement of steam generators;

- decontamination of equipment, rooms, buildings and facilities of NPP;

- equipment maintenance and repair;

- activities on mounting, dismantling and replacement of thermal insulation;

- construction and reconstruction works; 


\section{Chapter «Engineering sciences»}

- replacement of worn and spent part of equipment, consumables;

- replacement of worn work clothes, personnel protection means;

- implementation of sanitary and health protection measures in the controlled area.

The solid radioactive waste usually is:

- metal formed during replacement of the equipment and as a result of maintenance activities;

- woodware (stage, spacer, scaffolding);

- used individual protection means;

- rubber technical goods, cable products;

- filters of ventilation systems in auxiliary building and reactor hall;

- thermal insulation materials;

- construction waste (concrete chips, plaster);

- wipers, dusters;

- ash after radwaste processing at the burning facility;

- reactor internal devices and elements of reactor hall systems.

Transportation of SRW containers to the SRW storage located in the special building of Rivne NPP site is performed using special transport.

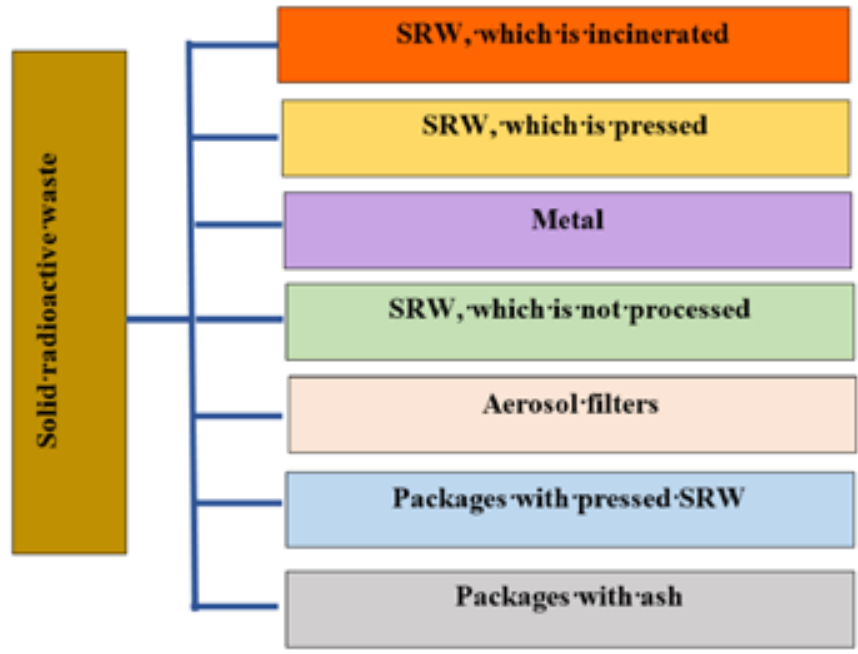

Figure 3. SRW distribution by types of treatment 
SRW management at RNPP includes:

- waste collection into plastic bags at the places of waste formation;

- primary sorting of waste with fragmentation (is necessary);

- waste transportation from the places of temporary collection;

- SRW sorting by its activity to low-level, intermediate-level and highlevel activity;

- SRW transportation by special vehicle OT-20 from the places of temporary collection into special building No2 (for power units 3, 4);

- SRW acceptance by the personnel of the decontamination and radwaste processing departments for temporary storage;

- SRW loading by the personnel of the decontamination and radwaste processing departments into cells of special building Nol of SRW storage (for power units 1,2) and special building No 2 of SRW storage (for power units 3,4).

According to CП AC-88 [13] all SRW, sorted by types and classification, are allocated for temporary storage in the SRW storage in the special building at Rivne NPP site.

The diagram of the SRW management at Rivne NPP is provided on Figure 4.

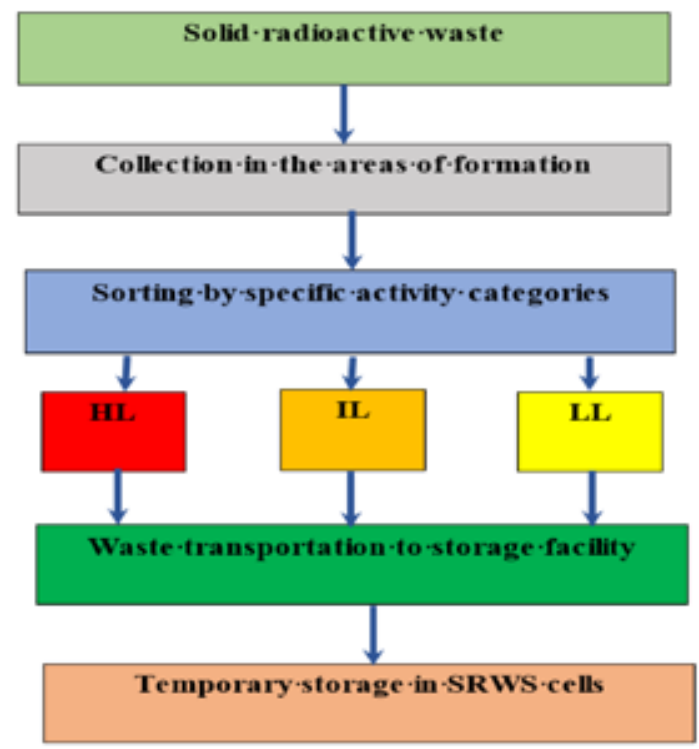

Figure 4. Diagram of the SRW management at Rivne NPP 
According to [13] all SRW, sorted by types and classified by activity, are allocated for temporary storage in the SRW storages in the special building at Rivne NPP site.

\subsection{Liquid radioactive waste management during operation of power units}

During plant operation, the liquid radioactive waste are generated in the process systems of the reactor department and auxiliary building as a result of the contact of water with fuel elements, contamination of oil systems, and operation of special water purification systems.

LRW are mainly met in the form:

- primary coolant uncontrolled leakages;

- contaminated oils;

- spent ion-exchange resins of the SWP system;

- waters that generate after decontamination;

- sewage waters from laundry hot shower drains;

- waters from hydraulic discharge of the filters;

- bottoms/residue;

- spent filtering materials of SWP system;

- SWP sludge.

Rivne NPP operates the transport bridge, which allows transmission of the drain waters and decantate of bottoms/residue from the auxiliary building 1 into auxiliary building 2 . The spent filtering materials (SFM) are transported by the hydro-transportation system into the tanks of radwaste storage (RWS), where they are stored under the layer of water.

The diagram of LRW management system is presented on Figure 5.

The analysis of the sources and amount of generated drains was conducted. Based on the analysis results, the correlation of sources was identified for LRW of each power unit, auxiliary building, and Rivne NPP in general. In addition, "Measures on minimization of liquid radioactive waste at Rivne NPP" were developed, which result in significant reduction of drain waters.

According to ДСП 6.177-2005-09-02 the liquid radioactive waste include:

- solutions of non-organic substances;

- pulps of filter materials;

- salt melt; 


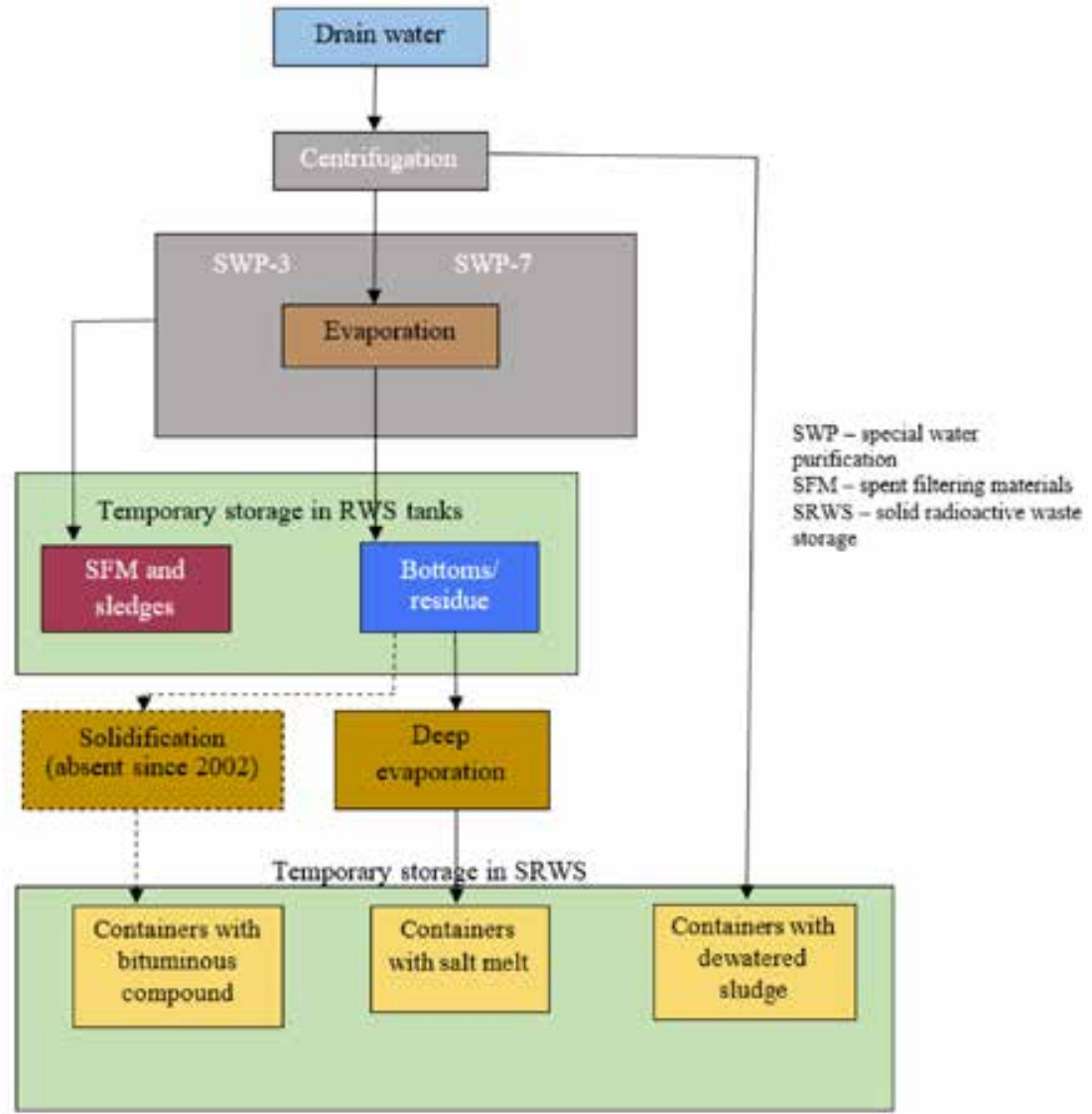

Figure 5. Diagram of LRW management system at Rivne NPP.

- organic liquids (oils, solvents), which have the following radiation characteristics:

- content of particular radionuclides that exceeds the allowed concentration established for water consumed by the population for drinking and household;

- content of radionuclide mixture is such that the total of ratio of specific activity of each individual radionuclide to the corresponding value is greater than one.

Table 3 presents characteristics of the main types of liquid radioactive waste. 


\begin{tabular}{|c|c|c|c|c|c|c|c|}
\hline \multirow{7}{*}{ 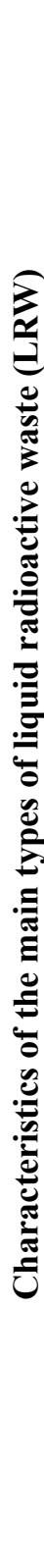 } & \multicolumn{7}{|c|}{ 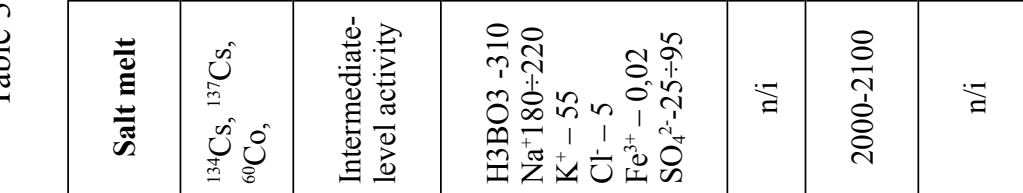 } \\
\hline & 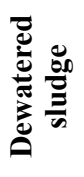 & $\sum_{\substack{\infty \\
\infty}}^{\infty} 0$ & 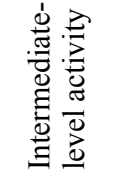 & $\Xi$ & 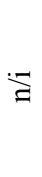 & $\stackrel{2}{2}$ & $\beth$ \\
\hline & 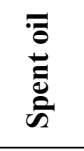 & $\sum_{\substack{0 \\
0}}^{0}$ & $\frac{\vec{D}}{\stackrel{0}{0}}$ & $\grave{\Xi}$ & 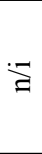 & $\grave{\beth}$ & $\grave{\beth}$ \\
\hline & 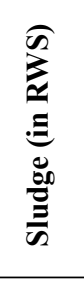 & $\sum_{0}^{0} \sum_{0}^{0}$ & 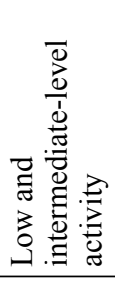 & 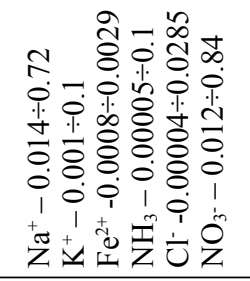 & $\stackrel{\vartheta}{\dot{p}}$ & $\frac{n}{8}$ & $\begin{array}{l}\stackrel{9}{\pi} \\
\stackrel{1}{r} \\
\text { r. }\end{array}$ \\
\hline & 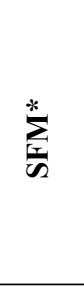 & $\sum_{0}^{0}$ & 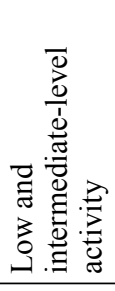 & 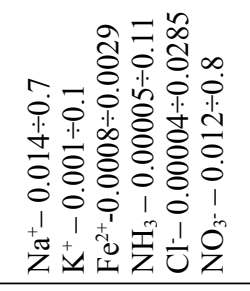 & $\stackrel{\vartheta}{\dot{p}}$ & $\begin{array}{l}\frac{0}{0} \\
\frac{1}{2} \\
\frac{2}{\alpha}\end{array}$ & $\begin{array}{l}\stackrel{9}{T} \\
\stackrel{1}{r} \\
\text { nं }\end{array}$ \\
\hline & 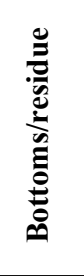 & 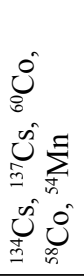 & 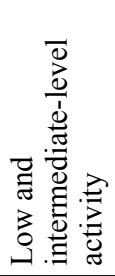 & 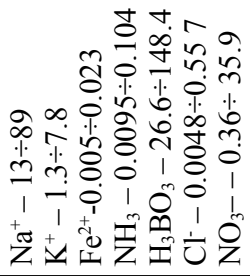 & $\frac{n}{\stackrel{r}{0}}$ & $\begin{array}{l}\stackrel{0}{7} \\
\stackrel{1}{1} \\
8 \\
\varrho \\
=\end{array}$ & $\begin{array}{l}0 \\
0 \\
1.0 \\
\end{array}$ \\
\hline & 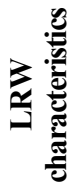 & 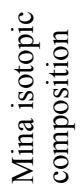 & 空密 & 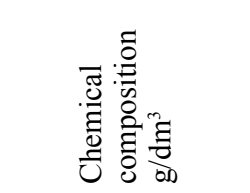 & $\stackrel{\pi}{2}$ & 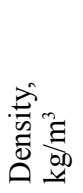 & 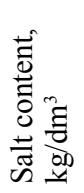 \\
\hline
\end{tabular}


During normal plant operation, the equipment is collected and stored in the special tanks of contaminated environment (effluents) - drain waters. Radioactive liquids and drains are obtained from the equipment of the reactor departments, and are generated as a result of operation of the special water purification system (SWP), decontamination of equipment and special protection clothes, sanitary and household discharge, laboratory discharge etc.

Following the procedure of treatment and evaporation at the SWP drain water evaporators, the liquid concentrate of salts is generated - evaporator residue/bottoms. The residue is stored in the special storage of liquid radioactive waste in the metal leak-tight tanks made on corrosion resistant steel, equipped with automated system indicating the LRW level and alarm system in case of a leakage. To exclude accidental LRW leakage into the environment, all tanks are placed in the reinforced-concrete rooms, encased with the sheets made of corrosion resistant steel up to the elevation of accidental spillage of tanks.

From the RWS the residue/bottom is sent to the deep evaporation facility (DEF) for processing, where more concentrated product is formed, which is placed to the container (with volume of $200 \mathrm{dm}^{3}$ ) and it gets into a solid phase during the cooling process. The containers with the salt melt (the product of the residue processing at the deep evaporation facility) is transported for the temporary storage to the solid radioactive waste storage facility (SRWS).

The analysis of the sources and amount of generated drains was conducted. Based on the analysis results, the correlation of sources was identified for LRW of each power unit, auxiliary building, and Rivne NPP in general. In addition, "Measures on minimization of liquid radioactive waste at Rivne NPP" were developed, which result in significant reduction of drain waters.

Rivne NPP operates the centrifugation facility (CF). This facility is intended for preliminary purification of drain waters from mechanic residues through centrifugation in the cycle of CWP system, as well as clearing of tanks, intended for collection and settling of drains, from accumulated sludge. The dewatered sludge, generated as a result of drains purification at the $\mathrm{CF}$, is placed into the container (volume of $200 \mathrm{dm}^{3}$ ) with further transportation to SRWS for temporary storage.

For purification of the technological media from the corrosion products and chemical mixtures, it SWP facilities are used, which contain ion-exchange filters. 


\section{Chapter «Engineering sciences»}

When the filters are in operation, the SFM are formed - ion exchange resins. The SFM are collected and stored in the RWS tanks under the layer of water.

According to the classification given in ОСПУ-2005 [10], the bitum compound does not relate to LRW.

Starting from 2013, the activity started with respect to transition of containers from SBC, which are stored in the RNPP's storage, to the CRWME for disposal.

The SNRIU, in general, agreed "Technical Solution on disposal of radioactive waste of Rivne NPP (in containers with salt-bitum compounds) at the production complex "Vector", which was prepared by the CRWME in 2014 [14].

With the Directive No60-p of NNEGC Energoatom as of 21.01.2015, the working group (WG) on the NPP Radwaste Optimization Strategy was established at the interdepartmental level. In the course of its activity, the working group developed the Extended Plan on Primary Actions for NPP Radwaste Optimization System and agreed it with NNEGC Energoatom. The action plan included activities for further treatment of the RNPP's SBC:

- analysis of the maps of SBC casks transportation and immobilization at the radwaste facilities of ChNPP and at CTRW of RNPP. As a result of the map analysis, the Technical Solution was updated with regard to shipment of Rivne NPP's SBC into Lot 3 for disposal;

- characterization of RNPP's SBC: analysis of shipment conditions for identification of the SBC radiation and chemical characteristics, preparation of the SBC characterization program, laboratory studies;

- preparation of SBC to transportation for disposal into the Lot 3 storage of CRWME: taking a decision on immobilization of casks with CBS, preparation of the Technical Specification for SBC packing, review, agreement as per the procedure and implementation of the Technical Solution on acceptance of the SBC for disposal in Lot 3 storage of CRWME. All specified activities are planned to be completed in 2018 .

The bitum compound accumulated at Rivne NPP is in the amount of $147.8 \mathrm{~m}^{3}$ (739 packages).

As of today, the complex of implemented activities include the SBC preparation to transporation to the CRWME.

The general diagram of the drain water and LRW treatment is presented on Figure 6.

List of available facilities/installations for LRW treatment at Rivne NPP are presented in Table 4. 


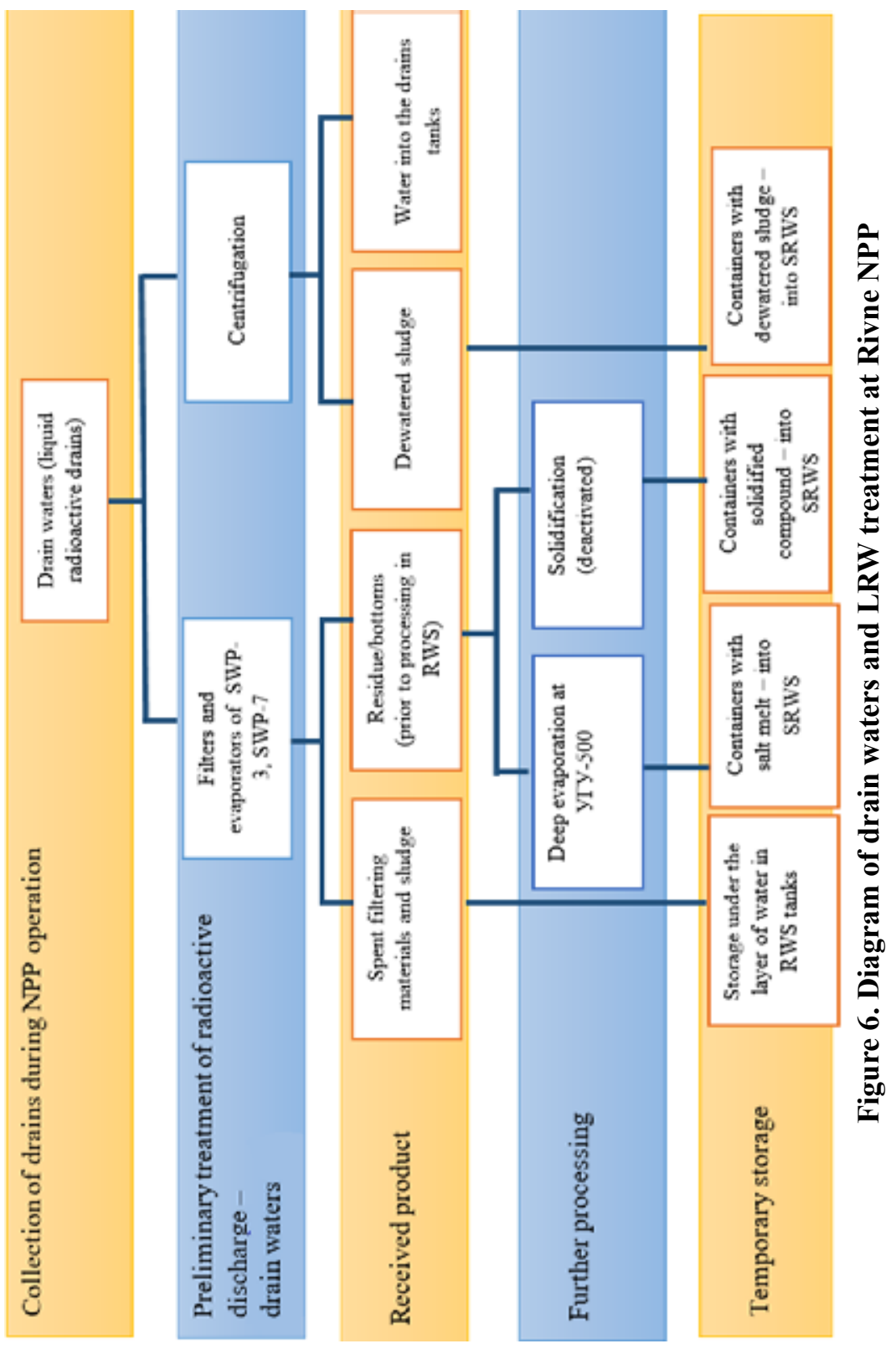


Chapter «Engineering sciences»

\section{LRW treatment facilities at Rivne NPP}

\begin{tabular}{|l|l|c|}
\hline \multicolumn{1}{|c|}{ Facility/installation } & \multicolumn{1}{|c|}{ Main function } & Design capacity \\
\hline $\begin{array}{l}\text { Evaporators of the drains } \\
\text { treatment system of SWP-3, 7 }\end{array}$ & Evaporation of drain waters & $6 \mathrm{~m}^{3} /$ year \\
\hline $\begin{array}{l}\text { Deep evaporation facility } \\
\text { (УГУ1-500M) }\end{array}$ & $\begin{array}{l}\text { Deep evaporation of drain } \\
\text { waters }\end{array}$ & $500 \mathrm{dm}^{3} /$ year \\
\hline $\begin{array}{l}\text { Solidification facility (with } \\
\text { rotor film solidifier PБ-800) }\end{array}$ & $\begin{array}{l}\text { Solidification of residue/ } \\
\text { bottoms }\end{array}$ & $150 \mathrm{dm}^{3} /$ year \\
\hline Centrifugation facility & $\begin{array}{l}\text { Purification of drain waters } \\
\text { from mechanic residues }\end{array}$ & $1.5-7 \mathrm{~m}^{3} /$ year \\
\hline
\end{tabular}

Accumulation of the liquid radioactive waste in the storage facilities at Rivne NPP as of 31.12.2017 is presented on Figure 7.

During 2017, the following volumes were accumulated at Rivne NPP:

$-380 \mathrm{~m}^{3}$ residue/bottoms;

$-3.6 \mathrm{~m}^{3}$ of spent filtering materials;

$-5.0 \mathrm{~m}^{3}$ of dewatered sludge ( 25 containers);

$-77.6 \mathrm{~m}^{3}$ of salt melt (388 containers).

The radioactive waste management at Ukrainian NPPs is characterized with absence of the completed technological cycle from the radwaste processing to receiving of the end-product, suitable for further long-term

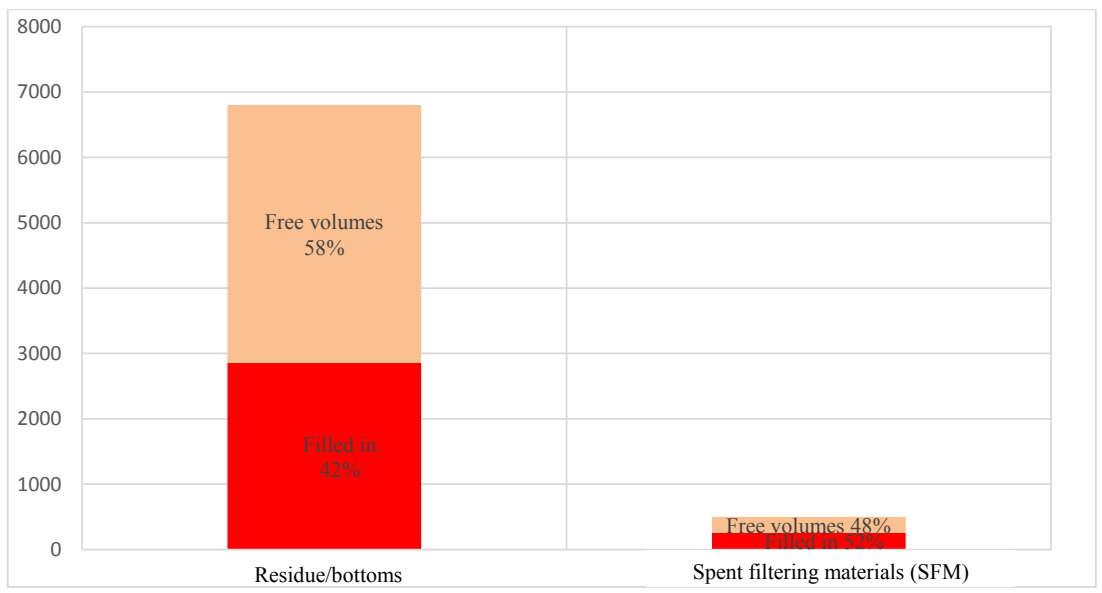

Figure 7. LRW accumulation in RWS at Rivne NPP 
storage or disposal. For this reason, the interdepartmental working group was created for solving the issues on radwaste optimization strategy in Ukraine, which included the representatives from NNEGC Energoatom, NPPs, STC, SNRIU, Ministry of Energy and Coal Industry of Ukraine, KIEP, Ministry of Health Protection of Ukraine, SAUMEZ, ChNPP (Directive by NNEGC Energoatom as of 21.01.2015 No 60-p. It was agreed that at the first phase of the working group's work it is reasonable to focus efforts on the improvement of the radioactive waste management system in Ukraine. To resolve the existing issues, the group developed "Extended Plan on Primary Actions for NPP Radwaste Optimization System" and got its approval on 09.03.2016. The issues related to further treatment of the SFM, salt melt, dewatered sludge are resolved with the efforts of the specified working group.

The following measures are in place: control of meeting the LRW formation and drain waters controlled levels, established in "Technical Specifications for radioactive waste formation and shipment to the storage facilities of Rivne NPP” 175-7-P-ЦД, continuous control of LRW shipment to RWS, implementation of the minimization measures related to residue/ bottoms accumulation, that reduce due to residue processing at the deep evaporation facilities.

Having stable operation of the deep evaporation facilities and activities implemented as per the schedule of "Comprehensive program for radioactive waste management at NNEGC Energoatom” ПМ-Д.0.18.174-16 [12], there will be sufficient free volumes in the RWS to ensure safe operation of power units of Rivne NPP, both during design and extended lifetime of the plant.

\subsection{Information of non-radioactive waste and waste management}

The dynamics of the non-radioactive waste accumulation in the sludge collector and polygon/landfill of Rivne NPP is presented in Table 5.

Table 5

Dynamics of the non-radioactive waste accumulation in the sludge collector and polygon/landfill of Rivne NPP

\begin{tabular}{|l|c|c|c|c|c|c|c|}
\hline & $\mathbf{2 0 1 1}$ & $\mathbf{2 0 1 2}$ & $\mathbf{2 0 1 3}$ & $\mathbf{2 0 1 4}$ & $\mathbf{2 0 1 5}$ & $\mathbf{2 0 1 6}$ & $\mathbf{2 0 1 7}$ \\
\hline $\begin{array}{l}\text { Sludge collector, } \\
\text { thous. tons }\end{array}$ & 139.154 & 161.746 & 184.227 & 161.683 & 132.664 & 116.978 & 133.636 \\
\hline $\begin{array}{l}\text { Polygon/landfill, } \\
\text { thous. tons }\end{array}$ & 14.164 & 19.727 & 25.133 & 29.113 & 32.794 & 36.789 & 42.193 \\
\hline
\end{tabular}




\section{Chapter «Engineering sciences»}

As a result of production activity, the non-radioactive waste of hazard classes 1-4 is generated at Rivne NPP:

- Hazard Class I: used luminescent lamps, used standard elements, used thermometers, which contain mercury.

- Hazard Class II: waste generated as a result of production processes and distribution of electrical, gas, steam and hot water energy, not indicated by any other way (packaging from chemically dangerous substances); batteries and other damaged or used storage batteries; damaged or used nickel-cadmium batteries (including the lantern); waste from additional materials and substances used in the nuclear energy field (expired chemical reagents).

- Hazard Class III: used oil products (sludge- and paste-like), used oil, used lubricants (paste-like), oily sand, used oily automobile filters, waste generated as a result of production processes and distribution of electrical, gas, steam and hot water energy, not indicated by any other way (packaging from diisopropylamine).

- Hazard Class IV: photo development solution for and solution of water-base substances, which speed up the development process - nonrevertible, photographic film and paper that contain silver or silver compounds - non-revertible (used radiographic film), used oily cloth, cans for paints (solid - barrels and cans), cans for lubricants (solid - barrels and cans), used tires with metal cord (solid), black metal scrap, colored metal scrap, waste paper, pharmaceutical products and substances (including veterinary), medical drugs and goods (including aerosols), their remnants damaged or used, expired or unidentified (expired potassium iodide pills), protection means from chemical or bacterial aerosols - damaged or used (respirators), used, damaged or dirty protection clothes (water suits), broken glass, worn out, damaged shoes (special protection shoes), used filtering material "Sipron", used organic-silicon material, remnants of the other film (printer film), used steel wire with oils, used medical waste - needles, syringes, ampullas, paints, enamels, lacquers, ink, damaged or used claying materials, their remnants, which cannot be used as intended, office and computer machines - non-revertible, plastic waste, non-revertible fixative solutions (fixers), construction waste (solid), food, sludge generated from water clearing, eye solutions, sawn or chipped wood, broken porcelain isolators (solid), mixed household waste (solid), used ion exchange resins (solid), waste after lime slaking, used thermal insulation material, sand-like 
abrasive material, used coal sorbent, used filtering material, abrasive metal dust, non-revertible abrasive products, slime after automobile transport washing, used sulphate slime mud, used wax, ozocerit, grease waste after cleaning of sewerage pipes.

About forty types of non-radioactive waste is formed or separately accumulated at Rivne NPP. The biggest amount of waste comes to the sludge formed after clearing of water, which is accumulated in sections C-1, C-3, C-4, C- 6 of water-isolated sludge collector, a facility with open water surface, banked with the embankment. In general, the sludge collecting system includes six sections (sections C-2 and C-5 for oil sludge of the purification facilities of sewage water containing oil products) and pump station for returning of settled water to the plant reverse systems. The characteristics of sludge collector are provided in Table 6.

Table 6

Characteristics of sludge collector

\begin{tabular}{|l|c|}
\hline Area of sludge collector & 0.6 ha \\
\hline Number of sections & 6 \\
\hline Capacity (design) & 226 thous. tons \\
\hline Volume of allocated waste as of 01.01.2018 & 133.636 thous. tons \\
\hline Number of operating surveillance wells/bores & 4 \\
\hline
\end{tabular}

The waste, that may be utilized and processes in Ukraine using relevant technologies and technical and/or economical prerequisites, are partially processed by the structural plant subdivisions. The waste is mainly taxable as the secondary products and transferred to the separate subdivision "Storage household" of NNEGC Energoatom, other entities and physical persons. This is a sludge formed as a result of water clearing, scrap of black and colored metals, used oils, paper and cardboard, polymers, glass, wood, textile, rubber (used automobile tires), photo materials containing silver compounds, spare details containing precious metal and stones.

The hazardous waste are collected separately by its type and transferred also through the separate subdivision "Storage household", but for decontamination and extraction - to the specialized facilities. The waste includes luminescent lamps and devices containing mercury, lead-acid 
storage batteries, oil sludges of the purification facilities of sewage water containing oil products, monitors, used batteries, unused drugs. Rivne NPP has a copy of license for collection, transportation, storage and extraction of: used oil products, including oils and mixtures; used luminescent lamps and used lead-acid storage batteries. Under the contract, the solid waste containing organic compound, which easily rotten, is transferred to the local municipal entity for extraction and sent to the polygon of the town of Varash.

The construction and industrial waste of Rivne NPP are extracted and shipped to the polygon, located $3 \mathrm{~km}$ from the town of Varash, at the location of the sand quarry. The drive way has a solid road. The perimeter of the polygon is surrounded with reinforced concrete plates. The first section of the polygon was operated from the beginning of RNPP commissioning and is recultivated at present; the second section has been closed since 2008. At the beginning of 2009, the waste is disposed at the third section of the polygon, which was accepted into operation in December 2007 with the act of the working commission. The place for the forth section is in standby. The waste of the hazard class 3, polluted with oil products (used absorbents, used filtering materials and used washing materials) are shipped to the polygon in the polyethylene packages.

Compacting and buildup of the construction and industrial waste at the polygon of Rivne NPP are performed using the bulldozer on the base of T-170 truck. The day watch is in place. Characteristics of the polygon/ landfill of industrial waste at Rivne NPPs is presented in Table 7.

Table 7

\section{Characteristics of the polygon/landfill of industrial waste at Rivne NPPs}

\begin{tabular}{|l|c|}
\hline Landfill area & 5 ha \\
\hline Number of maps & 4 \\
\hline Capacity (design) & 204.6 thous. tons \\
\hline Volume of allocated waste as of 01.01.2018 & 42.193 thous. tons \\
\hline Number of operating surveillance wells/bores & 2 \\
\hline
\end{tabular}

Non-radioactive waste management is implemented in accordance with the requirements of the environmental legislation, which are specified in "Instructions of non-radioactive waste management at 
Rivne NPP" and the Order with assignment of the responsible people. The accounting is accomplished in accordance with the generic form of primary accounting documents No1-BT "Accounting of waste and packing materials"; reports are prepared in accordance with the form of state statistic surveillance No1 - Waste (yearly) "Waste formation and management".

According to the data of laboratory studies conducted by the licensed laboratories, no negative impact was identified with regard to the state of atmospheric air, soils and ground waters at the waste extraction locations (sludge collector and polygon/ landfill of the construction and industrial waste).

\section{Conclusions}

The calculated and actual values of the radioactive contamination from the NPP show that the additional impact versus the natural background is not significant, it is 10 times less than the allowed one.

The ventilated air released through the ventilation stack of the plant is thoroughly cleaned and it practically has no such substances that can change the composition of the atmosphere.

Commissioning of the radwaste reprocessing complex will initiate implementation of the national policy program in the field of radioactive waste management aimed at protection of the environment, protection of life and health of the population from the impact of ionizing radiation, improvement of the operation conditions of the facility and replacement of the old equipment with the new one.

The following goals will be achieved with implementation of the project on Establishment of the Complex for Processing of Solid Radioactive Waste (CPSRW):

- minimization of the amount of radwaste, which is temporarily stored at Rivne NPP site;

- beginning of the process of solid radioactive waste (SRD) storage facilities emptying;

- rational usage of the capacities of the current SDW storages;

- reduction of the personnel doze rate;

- getting of the radwaste packages, which meet the requirements on the radwaste received for disposal in accordance with the norms and rules in effect in Ukraine. 


\section{References:}

1. "Nuclear Energy". Ukrainian Soviet Encyclopedia (USE): in 12 volumes / chief editor M.P. Bazhan ; Editorial board: O.K. Antonov and others - 2nd edition. K. : USE Chief editorial office, 1974-1985.

2. "Nuclear energy". Encyclopedia of Modern Ukraine: in 30 volumes / Editorial board I.M. Dzyuba [and others].

3. National Academy of Ukraine, Coordination Bureau for Encyclopedia of Modern Ukraine, National Academy of Ukraine. K., 2003-2016.

4. Law of Ukraine "On Usage of Nuclear Energy and Radiation Safety", News of the Verkhovna Rada of Ukraine. 1995, No 12, p. 81.

5. Solution on the Size and Border of the Controlled Area and Observation zone of Rivne NPP. No 132-1-P-11-ЦРБ.

6. DGN 6.6.1-6.5.001-98 "Norms of Radiation Safety of Ukraine. State Hygienic Standards (НРБУ-97).

7. Sanitary Rules for Design and Operation of NPPs.

8. Allowed Levels of Content of Radionuclides ${ }^{137} \mathrm{Cs}$ and ${ }^{90} \mathrm{Sr}$ in Products and Portable Water. Order No156 of the Ministry Of Health Protection of Ukraine as of 03.05.2006.

9. Technical Specifi cation for radiation monitoring of Rivne NPP.

10. DSP 6.177-2005-09-02. Main Sanitary Rules for Radiation Safety of Ukraine (OSPU-2005).

11. Report on the Status of Nuclear and Radiation Safety of Ukraine 2017. State Nuclear Regulatory Inspectorate of Ukraine in 2017. SNRIU, 2018. $81 \mathrm{p}$.

12. Radioactive Waste Management During Operation of NPPs of NNEGC Energoatom as of 31.12.2015, Ministry of Fuel and Coal Industry of Ukraine, NNEGC Energoatom, 2016, 104 p.

13. Sanitary Rules for Design and Operation of Nuclear Power Plants (CП АC-88/93).

14. Technical Solution on Disposal of the Radioactive Waste of Rivne NPP (containers with bitumen compound) at the "Vector" Production Complex, prepared by CRWME in 2014. 